\title{
Proposition of a Modern Theological Interpretation of Death as a Consequence of Sin
}

\section{Introduction}

Since the dawn of time, mankind was fascinated by the phenomenon of death, trembled before its inevitability, and desired to overcome it. This is testified by some of the oldest texts of ancient civilizations, in which the futility of the man's quest for immortality was described ${ }^{2}$. The Christian Revelation also addresses the issue, although it answers the eternal problem of death with completely different response: the Good News of salvation in Christ and life eternal, understood as the Lord's gift for a man, an invitation to participate in God's nature ${ }^{3}$. At the same time, it cannot be denied that both the Bible and the teaching of the Magisterium of the Church state that death - at least in some sense - is a consequence of $\sin ^{4}$.

Nowadays, many members of the modern Western civilization reject the Christian message that responds to the ancient urge of overcoming death. They instead seem to prefer to rather remove the issue of death from the cultural discourse $^{5}$. Perhaps they reject the Christian message (especially aforementioned

\footnotetext{
${ }^{1}$ Maciej Witała - doctoral student at the Faculty of Theology, Adam Mickiewicz University in Poznan, conducts research on the issue of the Fall of man and original sin and other protological problems in the context of natural sciences; e-mail: maciej.witala@gmail.com. ORCID: 00000003-0516-9983.

2 See e.g.: Epos o Gilgameszu, trans. \& ed. K. Łyczkowska et al., Warszawa 2002, tab. IX-XI, pp. 38-59.

${ }^{3}$ Dei verbum, no. 2-4. 7. 18.

${ }^{4}$ See e.g. Katechizm Kościoła Katolickiego, Poznań 2020, no. 1006-1007.

${ }^{5}$ See e.g.: J. Ratzinger, Eschatologia - śmierć i życie wieczne, trans. M. Węcławski, Poznań 1985, pp. 85-89; P. Bortkiewicz, Tanatologia. Czy istnieje nauka o śmierci? [in:] Śmierć $i$ wiara $w$ życie pośmiertne w świetle nauk przyrodniczych i humanistycznych, ed. M. Machinek, Olsztyn 2003, pp. 14-16.
} 
teaching on death as a consequence of $\sin$ ) because it seemingly contradicts the fact that phenomena such as aging, biological death, transience and succession of generations are not only universal but also necessary in our world. Without them, the emergence of the corporeal aspect of human nature, i.e. the emergence of man in the natural evolutionary process, would not be possible. Neither would be possible cultural progress of mankind and development of human civilization $^{6}$. Furthermore, as is well known, there has not been a golden age in history of mankind, in which humans enjoyed life expectancy far above the average as some theological explanations of death as a result of sin and cosmologies of the past ages would suggest ${ }^{7}$.

The reason for the apparent contradiction between catholic teaching about death as a result of sin and the fact that transience and death are necessary aspects of biological life, is perhaps the lack of a sufficiently comprehensive, contemporary theological interpretation of the doctrinal statements of the Magisterium. A superficial lecture of the Church's teaching on death as a consequence of sin may suggest that first humans were destined by the Creator to live forever on earth, and that there would be no biological death in the world if they had not sinned. Contrary to this, many prominent theologians nowadays state (see further) that the interpretation of biblical texts and the doctrinal statements of the Magisterium regarding the issue of death as a result of sin does not necessarily lead to the conclusion that the proto-mankind, in its primal "pre-sin" condition, was not meant to decease. These theologians assume that the sentence: "bodily death is the consequence of sin" may be interpreted in such a way that the experience of death (an objective phenomenon) has changed after the Fall of $\mathrm{Man}^{8}$ as a subjective experience, i.e. mankind experiences the death in a different way after sin than they did in their primal "innocent" state. Moreover, this interpretation implicates that the primary consequence of sin is not biological but spiritual death, i.e. a rupture of natural communion with God, possibly eternal.

In this article we propose a contemporary theological interpretation of the problem of death as a result of sin based on biblical and dogmatical data. The paper reports, in a shortened form, partial results of our research on contemporary challenges of the Catholic protology. Due to the limitations of the volume of this publication, its contents had to be limited to selected aspects of the problem.

${ }^{6}$ See Cz.S. Bartnik, Dogmatyka katolicka, vol. I, Lublin 2009, pp. 372-373; A. Tutaj, Gaśnięcie świadomości. Starzenie się i obumieranie ludzkiego mózgu [in:] Śmierć $i$ wiara $w$ życie pośmiertne $w$ świetle nauk przyrodniczych i humanistycznych, ed. M. Machinek, Olsztyn 2003, pp. 27-30.

${ }^{7}$ See E. Piotrowski, Kara wieczna a grzech pierworodny. Konieczność debaty, „Verbum Vitae" 36 (2019), pp. 308-310.

${ }^{8}$ I.e. Original Sin (lapsus protoparentum/pecatum originale originans). 
Therefore, the article is structured as follows:

1) In the first section, a brief analysis of the biblical data concerning death as a consequence of sin, with particular reference to the first chapters of Genesis, is included. Research is based on works of biblical scholars, and relies on the authority of specialists in the fields of biblical exegesis and interpretation

2) In the second section of the article, selected doctrinal statements, issued by the Magisterium of the Church over the centuries, related to the problem are presented

3) In the third section, the opinions of selected contemporary theologians, in whose works partial answers to the covered problem, consistent with our findings, could be already found, are briefly quoted

4) In the fourth section, the Mariological argument in favor of the proposed solution is covered.

The paper is concluded with a summary of the findings and proposed solutions to the difficulties outlined in the introduction.

\section{The Scripture on the issue of death as a consequence of sin}

An analysis of the biblical data on the issue of death as a result of sin should begin with initial pages of the Old Testament. The Book of Genesis opens with texts that are crucial for the interpretation of the subsequent books of the Bible?. When reading those passages it should be noted that the Inspired Authors used symbols and metaphors appropriate to their culture and their vernacular languages ${ }^{10}$. This is something that should be taken into consideration when analyzing the literal layer of these texts. One should also be aware that their authors did not intend to reflect historical facts or cover the issues of natural sciences, but rather existential or etiological truths. Even when they describe some historical events, the "historicity" of those should be understood rather in the "kairotical", not "chronological" aspect ${ }^{11}$.

In the creation narrative of the Book of Genesis, God calls the first men into existence and names them "Adam". This name is not only the individual name of

${ }^{9}$ Cf. Katolicki Komentarz Biblijny, trans. K. Bardski et al., ed. R.E. Brown, J.A. Fitzmyer, R.E. Murphy, Warszawa 2004, pp. 264-265.

${ }^{10}$ See Dei verbum, no. 12; 16; Verbum Domini, no. 38.

${ }^{11}$ Cf. Papieska Komisja Biblijna, Interpretacja Pisma Świętego w Kościele, trans. K. Romaniuk, Poznań 1994, pp. 67-68; A. Nossol, Teologia na ustugach wiary. Wokót zagadnień odnowionej teologii, Opole, 1978, p. 19; T. Jelonek, Biblijna historia zbawienia, Kraków 2004, p. 52; Z.J. Kijas, Początki świata i człowieka, Kraków 2004, pp. 37-39. 
the biblical protagonist (the first male of the narrative), but is also - or perhaps primarily - a "collective name" ${ }^{2}$. Its collective character is explicitly stated in Gen $5: 2^{13}$ as experts in the fields of exegesis and interpretation confirm ${ }^{14}$. Therefore, everything that the Bible says about Adam can be applied to all mankind ${ }^{15}$.

Taking that into account, an important aspect of the creation narrative and the story of the Fall of man from Gen 2-3 should be noted: in the second chapter of the Book of Genesis the Inspired Authors seem to express a belief in a strong relationship between man and matter. Although man is, unlike other creatures, endowed by God with a special breath of life at the moment of creation (Gen $2: 7)^{16}$, and in this respect separated from the natural world, creation narrative states clearly that, in the bodily aspect of his entity, man belongs to the world of nature. It is because humans were called into existence from the matter of this world like any other visible creature (biblical story depicts it as molding of man by the Creator from the dust of the earth - hebr. 'a $\bar{a} \bar{a} r)^{17}$. Moreover, the strong relationship of the human being with matter seems to be emphasized with the task to cultivate the garden in which man has been placed (cf. Gen 2:15) ${ }^{18}$. It is worth noting that, according to some scholars, one of many etymologies of the name "Adam" (other than one that refers to the aforementioned collective aspect of the

${ }_{12}$ See W. Trilling, Stworzenie i upadek wedlug Rdz 1-3, trans. E. Schulz, Warszawa 1980, p. 41; J. Ratzinger: Kościót - znak wśród narodów, vol. I, [Opera Omnia, VIII/1], Lublin 2013, p. 134; idem, Wprowadzenie do chrześcijaństwa, [Opera Omnia, IV], Lublin 2017; cf. Międzynarodowy komentarz do Pisma Świętego. Komentarz katolicki i ekumeniczny na XXI wiek, ed. W.R. Farmer et al., Warszawa 2000, p. 279; J. Lemański, Księga Rodzaju. Rozdziały 1-11 [in:] Nowy Komentarz Biblijny. Stary Testament, vol. I, part 1, Częstochowa 2013, pp. 166, 315. It should be noted that the idea of the unity of mankind in Adam was probably known to most of the Fathers of the Church: cf. M. Przyszychowska, Wszyscy byliśmy w Adamie. Jedność ludzkości w Adamie w nauczaniu ojców Kościoła, Poznań 2013.

${ }^{13}$ It is especially noticeable in the Septuagint translations. See Gen 5:2 [in:] New English Translation of the Septuagint, Oxford 2007 or R. Popowski, Biblia pierwszego Kościoła, Warszawa 2017.

${ }_{14}$ See S. Łach, Księga Rodzaju. Wstęp, przekład z oryginalu, komentarz, Poznań 1962, p. 192; J.B. Łach, Księgi Ludu Bożego Starego Przymierza: Pięcioksiag, Prorocy, Pisma. Ujęcie teologiczno-praktyczne, Poznań 2018, p. 58; Papieska Komisja Biblijna, Czym jest człowiek? Zarys antropologii biblijnej, trans. H. Witczyk, Kielce 2020, no. 14-19; W. Granat, Bóg Stwórca. Aniołowie-czlowiek, Lublin 1961, p. 263.

${ }^{15}$ Cf. Komisja Biblijna, Czym jest człowiek? Zarys antropologii biblijnej, no. 14-19.

${ }^{16}$ See J.B. Lach, Księgi Ludu Bożego Starego Przymierza: Pięcioksiag, Prorocy. Pisma: ujęcie teologiczno-praktyczne, pp. 57-58; S. Łach, Księga Rodzaju. Wstęp, przeklad z oryginatu, komentarz, pp. 199-200.

${ }^{17}$ See Gen 2:7: "The Lord God formed man of dust from the ground (...)"; Cf. Gen 2:19: "Out of the ground the Lord God formed every beast of the field and every bird of the air (...)".

${ }^{18}$ Cf. J.B. Łach, Księgi Ludu Bożego Starego Przymierza: Pięcioksiag, Prorocy, Pisma. Ujęcie teologiczno-praktyczne, p. 63; J. Lemański, Księga Rodzaju. Wstęp, przekład z oryginału, komentarz, rozdziaty 1-11, pp. 219-220; Międzynarodowy komentarz do Pisma Świętego. Komentarz katolicki i ekumeniczny na XXI wiek, pp. 264-265. 
name's bearer) also accentuates the strong bond between man and the material world ${ }^{19}$. Summarizing what was presented above, a thesis can be put forward that, according to the Scripture, transience may be seen as an integral part of the biological aspect of human existence. Man shares this trait with all other visible creatures as described in Eccl 3:19 et seq ${ }^{20}$ : "For the fate of the sons of men and the fate of beasts is the same; as one dies, so dies the other. They all have the same breath, and man has no advantage over the beasts; for all is vanity. All go to one place; all are from the dust, and all turn to dust again" 21 .

In next paragraphs a brief analysis of the biblical narration of the Fall of Man (Gen 2-3) will be presented. The story focuses on the Two Trees of Paradise: the Tree of Life and The Tree of Knowledge of Good and Evil22. A superficial reading of the narrative may suggest that, since his creation, man was biologically immortal, and that the bodily death appeared in this world as a punishment for reaching for the forbidden fruit of the Tree of Knowledge ${ }^{23}$. However, a thorough reading leads to different conclusions. Although in Gen 2:17 God warns man about the consequence of consuming the fruit of the Tree of Knowledge, which is death ${ }^{24}$, the warning in this statement probably does not refer to the biological demise. Inspired Authors rather used (as in many other passages of the Scripture) semantics relating to the bodily death to express the truths relating to the spiritual death ${ }^{25}$. The aforementioned passage reads: "of the tree of the knowledge of good and evil you shall not eat, for in the day that you eat of it you shall die"26. Therefore, it

${ }^{19}$ Hebrew name "Adam" is similar to the noun adamah - "soil, ground". Cf. Komisja Biblijna, Czym jest człowiek? Zarys antropologii biblijnej, no. 14-19; Międzynarodowy komentarz do Pisma Świętego. Komentarz katolicki i ekumeniczny na XXI wiek, p. 279; J.B. Łach, Księgi Ludu Bożego Starego Przymierza: Pięcioksiag, Prorocy, Pisma. Ujęcie teologiczno-praktyczne, p. 58.

${ }^{20}$ Cf. also: Ps. 90:3.5-6. 10a; Ps 39:5-8; 78:39; 102:12; 103:14-16; 144:4; Sir 17:1; 41:3-4.

${ }^{21}$ All biblical citations from Revised Standard Version Catholic Edition (San Francisco 2005), unless stated otherwise.

${ }^{22}$ See S. Łach, Księga Rodzaju. Wstęp, przekład z oryginatu, komentarz, p. 201; Cz.S. Bartnik, Dogmatyka katolicka, vol. I, p. 314.

${ }^{23}$ Cf. J.S. Synowiec, Początki świata i ludzkości wedlug Księgi Rodzaju, Kraków 2001, p. 156.

${ }^{24}$ Cf. J. Lemański, Księga Rodzaju. Wstęp, przekład z oryginału, komentarz, rozdziały 1-11, pp. 231-232; S. Łach, Księga Rodzaju. Wstęp, przekład z oryginału, komentarz, p. 220.

${ }^{25}$ See Cz.S. Bartnik, Dogmatyka katolicka, vol. I, p. 368.

${ }^{26}$ It is worth noting, that some Polish translations (incl. most popular Biblia Tysiaclecia) seem to imperfectly reflect the literal meaning of the discussed verse. In those translations it reads rather: "if you eat of it" [the forbidden fruit] "you will surely die". English translations prefer a variant of the immediate occurrence of the effects of consuming the forbidden fruit ("in the day you it of it, you shall die"), which seems to be more compliant to the Inspired Authors intentions. Septuagint

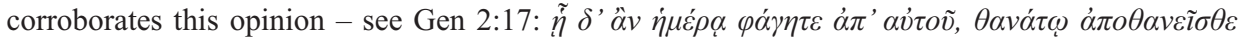
(Septuaginta id est Vetus Testamentum graece iuxta LXX interpretes, ed. A. Rahlfs, vol. I, Stuttgart 1962). Cf. J. Lemański, Księga Rodzaju. Wstęp, przeklad z oryginatu, komentarz, rozdziały 1-11, p. 231; cf. Cz.S. Bartnik, Dogmatyka katolicka, vol. I, p. 368. 
should be noted that if the consequence of consuming the forbidden fruit (representing $\sin$ ) had to be bodily death, the people of biblical narrative should have died immediately, and not only after reaching their full years and bearing offspring (cf. Gen 5:3-5). It seems logical then that the consequence of sin is death other than the bodily one, the one that affects not the corporeal, but the spiritual aspect of human nature. In addition, bodily death, as a phenomenon itself, should not be considered a result of reaching for the forbidden fruit of the Tree of Knowledge.

On the other hand, some exegetes state that, according to the narrative of the Fall, bodily death affected people because they lost the privilege of biological immortality, provided by consumption of the fruits of the Tree of Life ${ }^{27}$. This interpretation should be, however, ruled out on the basis of the literal layer of the text. For Gen 3:22 reads: "The Lord God said, 'Behold, the man has become like one of us, knowing good and evil; and now, lest he put forth his hand and take also of the tree of life, and eat, and live for ever'. This verse, as majority of biblical scholars agree, seems to clearly state that man had not been eating fruits of the Tree of Life before the Fall'"28.

It seems, therefore, that according to the Genesis 1-3 narrative, the man of the biblical story did not have access to bodily immortality by nature, nor did he have access to the fruits of the Tree of Life, which could provide biological immortality. It seems more probable, that the Inspired Authors perceived bodily death and transience as integral aspects of human nature ${ }^{29}$. Even the story of exile from the Paradise does not suggest that the biological death started to affect man as a punishment for sin. On the contrary, death is presented as an end to the existential torment of the earthly struggle that befell man after $\sin ^{30}$. It can be concluded that the initial passages of the Bible indicate that mortality and transience are natural aspects of human existence ${ }^{31}$.

Therefore, a thesis can be put forward that the story of the Garden of Eden does not contain a message about the golden age in the prehistory of mankind, as theologians of the past ages stated. Although those scholars accepted (e.g. St. Thomas Aquinas) that the people in paradise were of mortal nature, they also assumed that

${ }^{27}$ This variant of interpretation is included in the $5^{\text {th }}$ edition of Biblia Tysiaclecia, as well as in translation \& commentary: S. Łach, Ksiega Rodzaju. Wstęp, przeklad z oryginału, komentarz, pp. 206, 220, 222.

${ }^{28}$ See e.g.: Katolicki Komentarz Biblijny, p. 17; J. Lemański, Księga Rodzaju. Wstęp, przekład $z$ oryginatu, komentarz, rozdziaty 1-11, p. 258. On the other hand, some scholars state that it is not certain if, according to the biblical narrative, man in paradise had access to the Tree of Life or not - see e.g.: W. Trilling, Stworzenie i upadek wedtug Rdz 1-3, pp. 138-139.

29 J.S. Synowiec, Początki świata i ludzkości wedlug Księgi Rodzaju, pp. 160-161.

${ }^{30}$ Cf. Katolicki Komentarz Biblijny, p. 18; S. Łach, Księga Rodzaju. Wstęp, przektad z oryginatu, komentarz, p. 220; T. Jelonek, Biblijna historia zbawienia, p. 59.

${ }^{31}$ See Papieska Komisja Biblijna, Czym jest człowiek? Zarys antropologii biblijnej, no. 16, 22. 
the first men enjoyed the supernatural gift of immortality before the Fall ${ }^{32}$. The opinion of many contemporary theologians is definitely more consistent with the correct interpretation of biblical data. They assume that the symbolism, contained in the literal layer of the Gen 2-3 text, is used to convey a message about the moral trial: a verification of the relationship of man to the Creator, that took place at the dawn of mankind ${ }^{33}$. According to this modern interpretation, the Tree of Life and the Tree of Knowledge refer to the two values reserved only to God: the eternal life and the "knowledge" of good and evil, that is, prerogative of arbitrarily establishing moral norms ${ }^{34}$. Reaching for the fruit of the Tree of Knowledge (despite the Creator's warning) would, therefore, mean breaking the primal, trustful, lifegiving relationship with $\mathrm{God}^{35}$ in favor of pursuing the desire to become like God, following the satanic temptation of total autonomy (see Gen $3: 1-5)^{36}$. The expulsion of the first men from Paradise and denial of access to the fruits of the Tree of Life in the narrative indicates that they failed the aforementioned moral trial. As a consequence, their relationship with God and harmony with their natural environment deteriorated (cf. Gen 3:7-24). If we accept this variant of interpretation of the narration of the Fall, we must conclude that the paradise gift of immortality can only be understood as an unrealized possibility conditioned by the successful passing of the aforementioned primordial trial ${ }^{37}$. Moreover, this possibility should be probably interpreted in a purely eschatological perspective. Therefore, the death that God warned against (see Gen 2:17) is first and foremost a spiritual death, that is, a state of separation from communion with $\mathrm{God}^{38}$.

The interpretation of Genesis 2-3 presented above is based on a comprehensive reading of both the Old and New Testaments. However, even a cursory

${ }^{32}$ See STh, 1a, q. 97, a. 1; cf. Papieska Komisja Biblijna, Czym jest czlowiek? Zarys antropologii biblijnej, no. 11.

33 See Cz.S. Bartnik, Dogmatyka katolicka, vol. I, p. 344.

${ }^{34}$ See J. Lemański, Księga Rodzaju. Wstęp, przekład z oryginału, komentarz, rozdziały 1-11, p. 201; A. Tronina, Drzewo życia w rajskim ogrodzie. Biblijne korzenie mistyki Krzyża, Częstochowa 2017, p. 42.

${ }^{35}$ See Międzynarodowy komentarz do Pisma Świętego. Komentarz katolicki i ekumeniczny na XX wiek, p. 279, cf. Księgi Ludu Bożego Starego Przymierza: Pięcioksiag, Prorocy, Pisma. Ujęcie teologiczno-praktyczne, p. 71; cf. A. Tronina, Drzewo życia w rajskim ogrodzie. Biblijne korzenie mistyki Krzyża, p. 44; cf. T. Stanek, Pięcioksiag jako narracja symboliczna, Poznań 2014, p. 42.

${ }^{36}$ See Międzynarodowy komentarz do Pisma Świętego. Komentarz katolicki i ekumeniczny na XXI wiek, p. 280; cf. Katechizm Kościoła Katolickiego, no. 397-398; Księgi Ludu Bożego Starego Przymierza: Pięcioksiag, Prorocy, Pisma. Ujęcie teologiczno-praktyczne, p. 65; cf. A. Tronina, Drzewo życia w rajskim ogrodzie. Biblijne korzenie mistyki Krzyża, p. 44; G.L. Müller, Dogmatyka katolicka, trans. W. Szymona, Kraków 2015, p. 165.

${ }^{37}$ Cf. J. Lemański, Księga Rodzaju. Wstęp, przekład z oryginału, komentarz, rozdziaty 1-11, p. 231.

${ }^{38}$ Cf. Katolicki Komentarz Biblijny, p. 18; J. Lemański, Księga Rodzaju. Wstęp, przekład z oryginalu, komentarz, rozdzialy 1-11, pp. 260-262. 
examination of the most significant biblical data about human death seems to corroborate this proposal. First and foremost, the Scripture clearly distinguishes between bodily and spiritual death. Bodily death affects everyone, while spiritual death is the fate of sinners and, therefore, causes righteous fear in them (cf. e.g.: Ezek 18:1-9.23 et seq; Tob 12:9-10; Job 42:7-8; Ps 90:3.5-6; Sir 17:1 et seq; Wis 1:14-16). A sinner affected by spiritual death (the one having consequences in eternity) enters the state of living death, even during his corporeal life (cf. e.g.: Eph 2:1-7; Matt 10:28). Jesus Christ the Redeemer saves man from this kind of death (cf. e.g.: Heb 2:14-15; Rom 8:1-2) as Christ Himself is the way to the true life: "And this is eternal life, that they know thee the only true God, and Jesus Christ whom thou hast sent" (John 17:3)

It is also worth noting, that reading the Sacred Scripture in its entirety leads to discovery of a compositional clamp that binds all biblical books together with the symbol of the Tree of Life: from the Book of Genesis (as presented above) to the Book of Revelation (v. Rev 2:7; 22:2.14.19). The eschatological image of the life-giving tree in the Heavenly Jerusalem leads to the proper interpretation of the symbol of the Two Trees of Paradise. Man who had been given a chance to develop close relationship with Creator and participate in God's Life (represented by the symbolism of the Tree of Life), lost this chance as a result of misusing his freedom (represented by "reaching" for the fruit of the Tree of Knowledge). The access to the source of the true life is ultimately restored through Jesus Christ ${ }^{40}$. The interpretation proposed above was excellently summarized in the beginning of the $4^{\text {th }}$ century by St. Methodius of Olympus:

Now, when [man] inclines to corruption, he becomes corrupt and mortal, and when to incorruption, he becomes incorrupt and immortal. For, being placed midway between the tree of life and the tree of the knowledge of good and evil, of the Fruit of which he tasted, he was changed into the nature of the latter, himself being neither the tree of life nor that of corruption; but having been shown forth as mortal, from his participation in and presence with corruption, and, again, as incorrupt and immortal by connection with and participation in life ${ }^{41}$.

39 According to Hebrew etymology, knowing someone refers to close, familiar relation with that person. In this case it may be referred to communion and unity with life giving God. Cf. R.E. Brown, I Bogiem było słowo. Komentarz do Ewangelii wg św. Jana, trans. A. Gomola, Kraków 2010, p. 220.

${ }^{40}$ Cf. M. Witała, Grzech pierworodny: współczesne trudności i propozycja zastosowania chrystocentrycznej symboliki drzew rajskich w narracji teologicznej, ,Teologia Dogmatyczna” vol. XV (2020), pp. 209-224. Cf. also: A. Tronina, Drzewo życia w rajskim ogrodzie. Biblijne korzenie mistyki Krzyża, pp. 152-153.

${ }^{41}$ Methodius of Olympus, The Banquet of the Ten Virgins or Concerning Chastity, discourse III, chapter 7, trans. W.R. Clark [in:] The Writings of Methodius, Alexander of Lycopolis, Peter of Alexandria and several fragments, ed. A. Roberts, J. Donaldson, Edinburgh 1869, pp. 1-119. 


\section{Selected doctrinal statements of the Magisterium of the Church about death as a consequence of sin and a proposal for a contemporary interpretation}

In the following part of the paper, the interpretation of biblical data on death as a result of the Fall presented in the previous section will be confronted with the synthesis of the teaching of the Magisterium on the subject. To make it possible, it is necessary to analyze the evolution of doctrine over the centuries.

The earliest doctrinal statements regarding death as a result of sin were formulated by the local synods, in response to specific problems and doubts. In 253, in Carthage, the necessity of infant baptism was emphasized. The Fathers of the Synod reminded that even infants are affected by the "plague of ancient death" Also in Carthage, in 411, amidst the Pelagian crisis, the synod stated that Adam was not created mortal but died as a result of sin, and through him all mankind inherited mortal nature. However, such a statement would be later regarded as heterodoxy in doctrinal teaching of a higher rank ${ }^{43}$. Successive synods: in Diospolis (415), Carthage (416 and 418) and Milevum (416) developed the idea of death that began to affect man after the sin of Adam as an opposition to the teaching of Pelagians. In the statements of those synods, both bodily and spiritual death were listed as the results of the first $\sin ^{44}$.

In the documents of the aforementioned Carthaginian Synod of 418 it is stated: "whoever says that Adam, the first man, was made mortal, so that, whether he sinned or whether he did not sin, he would die in body, that is he would go out of the body not because of the merit of sin but by reason of the necessity of nature, let him be anathema" ${ }^{45}$. The terminology used suggests that bodily death is a direct result of sin, and that man was created as bodily immortal. Such doctrine would contradict later statements of the Magisterium, as mentioned above. Oddly enough, the teaching of the Synod of Carthage of 418 was approved by Pope Zosimus in a letter addressed to the Eastern Churches known as Epistula Tractatoria $[\text { vel Tractoria }]^{46}$. The terminology used in the aforementioned Pope Zosimus' letter, allows, however, for a quite contradictory interpretation since the teaching on death as a result of sin teaching was presented in it from a completely different perspective:

${ }^{42}$ See Acta synodalia I, pp. 12-15.

${ }^{43}$ See Acta synodalia II, pp. 185-186. Cf. Pius V, Ex omnibus afflictionibus (1567) that condemned the statement: The immortality of the first man was not a benefit of grace, but a natural condition - Enchiridion symbolorum, no. 1078; cf. also: Pius VI, Constitution Auctorem fidei (1794) - Enchiridion symbolorum, no. 1517.

${ }^{44}$ See Acta synodalia II, pp. 203-204. 216-219. 224. 246 et cf. Historia dogmatów II, pp. 156-158.

${ }^{45}$ Enchiridon symbolorum, no. 101. For Polish trans. cf. Acta synodalia II, p. 246 et seq.

${ }^{46}$ Historia dogmatów II, p. 158. 
It is written: "If the Son liberates you, you will be truly free" [John 8:36]. For through Him we are reborn spiritually, through Him we are crucified to the world. By His death that bond of death introduced into all of us by Adam and transmitted to every soul, that bond contracted by propagation is broken, in which no one of our children is held not guilty until he is freed through baptism ${ }^{47}$.

In this text, there is no mention of bodily death as a result of sin, but of the bond of death "introduced into" [mankind] by Adam. It seems that it refers rather to the spiritual, not the corporeal condition of man, hence the mention of "spiritual rebirth" in Christ, liberating from the bondage of death.

An important testimony of the papal and conciliar teaching on death as a result of sin at the end of antiquity is the document called Tomus ad Flavianum (449) issued by Leo the Great. It is usually omitted in the compilations of the significant protological statements of the Magisterium, perhaps due its main subject as it concerns primarily Christology. In Tomus, the pope stated:

The devil was glorying in the fact that man, deceived by his craft, was bereft of divine gifts and, being stripped of his endowment of immortality, had come under the grievous sentence of death, and that he himself, amid his miseries, had found a sort of consolation in having a transgressor as his companion ${ }^{48}$.

Moreover, it was stated that mortality belongs to human nature, assumed by the Son of God in His Incarnation. The quoted passage allows for a conclusion that the death sentence, shared by man with Satan, refers to eternal, spiritual death. The significance of spiritual death as a result of sin is also emphasized by the documents of the Synod of Orange, in which it was stated that the Fall resulted not only in bodily death, but also in the death of the soul ${ }^{49}$.

The teaching of the Magisterium on death as a consequence of sin in the subsequent centuries followed the outlines of the ancient statements of the Magisterium cited above. However, the emphasis is put on the spiritual death, that is, the state of "not-being-saved", the inability to enter the Kingdom of Heaven, as stated in the Decree for the Armenians (1439) of the Council of Basel-Ferrara-Florence ${ }^{50}$. This doctrinal stance is also reflected in the teaching of the Council of Trent. Its Decree on Original Sin (1546) recapitulates the previous teaching on this matter ${ }^{51}$. It was

47 Enchiridion symbolorum, no. 109a.

${ }^{48}$ Trans. from: A Selected Library of the Nicene and Post-Nicene Fathers of the Christian Church, ed. P. Schaff, H. Wace, Edinburgh 1899, p. 255. Cf. Dokumenty Soborów I, pp. 196-213.

${ }^{49}$ See Acta synodalia IV, pp. 128-132.

${ }^{50}$ See Enchiridion symbolorum, no. 696. Cf. Dokumenty Soborów III, p. 509.

${ }^{51}$ See Council of Trent, Decree on Original Sin (1546) [in:] Enchirdion symbolorum, no. 787-792. Cf. Dokumenty Soborów IV, pp. 235- 241. 
emphasized again that man, with the death he brought upon himself with sin, fell into the slavery of the devil, and that the results of the Fall apply to both body and soul ${ }^{52}$. It should be noted that the analysis of canons 3-4 of the Decree leads to the conclusion that the predominant consequence of the Original Sin indicated in the document is spiritual death, that is, a state of deprivation of eternal life. Therefore, as in the previous statements of the Magisterium related to the regarded issues, the fathers of the Council of Trent emphasized the importance of the baptism of the infants ${ }^{53}$.

Thus, it can be argued that in the most important statements of the Magisterium of the Church since ancient times, the doctrine regarding death as a consequence of sin was consolidated as follows: the most important consequence of the Fall is spiritual death, understood as a state of not-being-saved, disability to enter the Kingdom of Heaven and deprivation of eternal life. In a certain sense, bodily death is also a consequence of sin, although, obviously, as a phenomenon in itself it is an inherent part of human nature. Although the oldest statements of local synods expressed opinion that man was not created mortal, later documents (of the rank of universal teaching) clearly stated that humans are of mortal nature.

The doctrine of death as a consequence of sin, developed up to the Council of Trent, is reflected in the contemporary teaching of the Magisterium. This can be summarized by the statement contained in the Pastoral Constitution on the Church in the Modern World (1965). In number $18^{\text {th }}$ of the document, it is stated that due to the "eternal seed that man bears in himself, he rebels against death". However, "prolongation of biological life is unable to satisfy that desire for higher life which is inescapably lodged in his breast, for man has been created by God for a blissful purpose beyond the reach of earthly misery" ${ }^{\prime 4}$. According to this statement, people were not created for an endless biological life, in which bodily death would not affect them. However, in the next statement council states: "In addition, that bodily death from which man would have been immune had he not sinned will be vanquished, according to the Christian faith, when man who was ruined by his own doing is restored to wholeness by an almighty and merciful Saviour" ${ }^{55}$. Therefore, on the one hand, it is stated that the goal of man's existence is eternal life after the resurrection ${ }^{56}$, not an infinite earthly life, but on the other hand, it is stated that man would have been free from death if he had not sinned.

A similar difficulty appears in the Catechism of the Catholic Church. While it portrays death as a result of $\sin ^{57}$, it also states: "In a sense bodily death is natural,

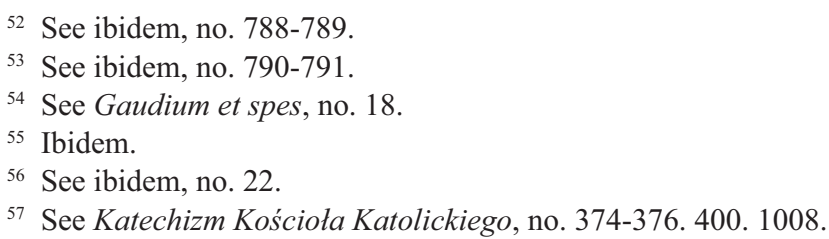


but for faith it is in fact 'the wages of sin'. (...) Death is the end of earthly life. Our lives are measured by time, in the course of which we change, grow old and, as with all living beings on earth, death seems like the normal end of life"

The authors of the Catechism also emphasize that through the Paschal Mystery of Jesus Christ, the "curse of death" was transformed "into a blessing" 59 . In the above statements of the Catechism, the following difficulty can be pointed: bodily death is presented in three, seemingly contradicting aspects: as a natural part of human life; as a punishment for sin; and, through Jesus Christ, as a blessed passage to eternal life ${ }^{60}$.

How to solve this difficulty? Taking into account previously presented results of the biblical data analysis and the fact that the statements of the Magisterium quoted earlier, especially those of the highest rank, emphasized the importance of spiritual and eternal death, the following interpretation of the doctrine of death as a consequence of sin can be proposed:

1) The most principal consequence of the Fall is spiritual, eternal death, i.e. rupture of communion with God. It results in the inability to enter eternal life. However, by the Paschal Mystery of Christ, into which man can become immersed through Baptism, this consequence of sin may be overcome

2) Bodily death could be called a "secondary" consequence of sin, but this statement requires clarification. Although bodily death is a natural part of earthly life, and the only transition to eternal life, it is no longer experienced as such after the Fall. Due to being affected by sin, man perceives death as a tragic occurrence and cannot come to terms with the inevitable fate. The true, original meaning of bodily death has been restored by Christ, and as such it can be experienced by Christians.

It is worth mentioning that this kind of interpretation has already appeared in the publication which could be considered as a form of teaching of the local Church. In Catholic Catechism for Adults issued and authorized by German Bishops' Conference it is stated:

Through sin came death. It does not mean that man in Paradise was to live an earthly life without an end. In our finite, transient world, biological life without death is unthinkable. The Bible, however, does not teach about death in biological sense, but about death as a real personal experience of human being, full of

\footnotetext{
${ }^{58}$ Ibidem, no. 1006-1007.

59 Ibidem, no. 1009.

${ }^{60}$ See ibidem, no. 1010-1013.
} 
suffering and fear, which man, with his will to live, abhors and tries to preserve himself from. God did not want this kind of death, as it is a manifestation of $\sin$, a sign of man's separation from God, the source of life ${ }^{61}$.

The problem with the proposed interpretation is that some of the statements of the Magisterium of the Church quoted earlier used the terminology that, in some cases, suggested that at the dawn of mankind the first men existed in a state of real bodily immortality. Similar teaching about the supernatural gifts (including immortality), enjoyed by the first men in Paradise, was widespread in the theology of the past ages ${ }^{62}$. This difficulty could be probably explained by ancient cosmological thinking, in which the vision of a golden age of the early days of mankind was something common ${ }^{63}$. It will be investigated further in the next section of the paper, in which the opinion of Cardinal Gerhard Ludwig Müller is cited.

\section{The issue of bodily death as a result of sin in the works of selected contemporary theologians}

In the writings of recognized Catholic theologians, a response (at least partial) to difficulties related to the issue of death as a result of sin can be found. Their solution to the problem is consistent with findings presented in previous sections of our paper. Karl Rahner, for example, noted that bodily death can be called a consequence of $\sin$ in the sense that its meaning for man, after the Fall, has changed. The problem of bodily death and other manifestations of physical evil was explained by Cardinal Rahner when stating that the attitude of a human person to the surrounding world, including the "physical evil", would be different if human existence was not determined by $\sin ^{64}$. Thus, the Fall, somehow defining human existence, influences the way in which the struggle with the reality of earthly life including disease and death are experienced by him. According to the German Jesuit, if the man had not sinned, death would have completely different character for mankind. It would be experienced as a natural end of earthly life and a transition to the ultimate goal of existence ${ }^{65}$, beyond the boundaries of mortality ${ }^{66}$.

${ }^{61}$ Niemiecka Konferencja Biskupów, Katolicki katechizm dorostych. Wyznanie wiary Kościoła, trans. M. Węcławski, Poznań 1991, p. 389.

62 See e.g. W. Granat, Bóg Stwórca. Aniołowie-człowiek, p. 351 et seq.; also p. 385 et seq.

63 See T. Jelonek, Biblia a mity o raju i złotym wieku, Kraków 2010, pp. 97-125.

${ }^{64}$ See K. Rahner, Podstawowy wykład wiary. Wprowadzenie do pojęcia chrześcijaństwa, trans. T. Mieszkowski, Warszawa 1987, pp. 98-99.

65 Ibidem, p. 99.

${ }^{66}$ Cf. ibidem, p. 222 et seq. 
Another representative of the Society of Jesus, Card. Luis Ladaria Ferrer, approaches the problem differently, but reaches similar conclusions. The current (2021) prefect of the Congregation for the Doctrine of the Faith states that although the biblical terminology of death is not unambiguous ${ }^{67}$, the immortality to which the Creator called man must be certainly understood as an eschatological feature ${ }^{68}$. Card. Ladaria, however, refrains from stating whether bodily death, as a phenomenon in itself, can be regarded as a consequence of sin or merely as a subjective human experience ${ }^{69}$.

The findings presented in our work so far have been more compliant with the latter of the proposals. A good summary of opinions of cited Jesuit theologians can be found in a publication of the German theologian Wolfgang Trilling, according to whom after sin death took on its full meaning. It became, after the Fall, a dramatic end to earthly life - as bodily death, and a state of not-beingsaved, deprivation of eternal life - as spiritual death ${ }^{70}$.

In the previous section, the difficulties were mentioned that arise when the proposed interpretation of death as a consequence of sin is juxtaposed with some statements of the Magisterium suggesting that man before the Fall actually enjoyed supernatural gifts, i.e. existed in alleged state of the "golden age". A solution to this problem can be found in writings of Gerhard Ludwig Müller, the predecessor of the Cardinal Ladaria as Prefect of the Congregation for the Doctrine of the Faith. According to Cardinal Müller, traditional teaching on preternatural gifts, including bodily immortality, needs a contemporary interpretation. It should be taken into account that the subject of theological teaching about the original state of mankind is not the material, biological or cultural state of the first men, but their transcendental condition, and in particular, the possibility of free choice of fulfillment in relation to God (but also rejecting this relation) ${ }^{71}$. As the German dogmatist rightly points out, this thesis stems from the fact that the biblical narrative of protology is not intended to recreate the historical memory of origins of mankind or to present mythical cosmology, but to convey Israelite's religious reflection on the relationship of man with God, based on the experience of salvation ${ }^{72}$. Thus, biblical images, especially the symbol of the Garden of Eden, and theological statements about preternatural gifts should not be interpreted as testimony of the golden age at the dawn of mankind, but as an expression of the experience of the original, sinless relationship with God, harmony

${ }^{67}$ See L.F. Ladaria Ferrer, Wprowadzenie do antropologii teologicznej, trans. A. Baron, Kraków 1997, p. 99.

${ }^{68}$ See ibidem, pp. 99-100.

${ }^{69}$ See ibidem.

${ }^{70}$ See W. Trilling, Stworzenie i upadek wedtug Rdz 1-3, p. 139.

${ }^{71}$ See G.L. Müller, Dogmatyka katolicka, p. 161.

72 Ibidem, p. 160. 
with oneself and the surrounding world ${ }^{73}$. The preternatural gift of immortality should be understood primarily in an eschatological sense ${ }^{74}$.

The problem of death as a result of sin was also raised by Polish theologians, of which the most insightful was probably Fr. prof. Czesław Stanisław Bartnik. In his work entitled Dogmatyka Katolicka [Catholic Dogmatics], he stated that the phenomenon of bodily death would have also affected mankind if man had not sinned, it would not, however, have been experienced by human being as a tragic occurrence ${ }^{75}$. Prof. Bartnik noted that the doctrine of the theologians of the past on the real biological immortality of the first men was a result of misinterpretation of biblical texts, the authors of which used the image of bodily death to convey the truth that the primary consequence of sin is spiritual death, i.e. breaking of the communion with $\mathrm{God}^{76}$. Moreover, it should be noted that if man were destined for eternal life not in an eschatic but an earthly aspect, human nature would be internally discrepant. Furthermore, the entire coherence and logic of the history of salvation would seem inconsistent ${ }^{77}$. The Lublinian theologian wrote that without transience, bodily death and the succession of generations, "life on earth would be meaningless or even like hell. God's creative act would be devoid of rationality, goodness, and harmony. Everything would become nonsense" 78 . Thanks to Christ, however, man is able to understand the meaning of his bodily death as the end of earthly life that allows man participate in Christ's redemptive history ${ }^{79}$.

Similar conclusions regarding the bodily death of man before the Fall were already published half a century ago by Fr. prof. Ignacy Różycki. The opinion of this theologian is significant as it was developed on the basis of a careful analysis of the Decree on Original Sin of the Council of Trent. Prof. Różycki stated that the doctrine of bodily immortality of the first men was not intended to be an integral element of the dogmatic decisions of the Council ${ }^{80}$. Such doctrine cannot be even defined a part of the ordinary universal teaching of the Church, but only as one of the possible theological interpretations ${ }^{81}$.

To summarize opinions reviewed above, it can be stated that the interpretation of biblical data and the teaching of the Magisterium on death as a result of sin, proposed in the previous section, is already endorsed by some renown

73 See ibidem, p. 163.

74 See ibidem, p. 157 et seq.

75 See Cz.S. Bartnik, Dogmatyka katolicka, vol. I, p. 372, also vol. II, pp. 464-465.

76 See ibidem, vol. I, pp. 371-372. 491; vol. II, pp. 829-831.

77 See ibidem, vol. II, pp. 371; vol. II, p. 536.

78 Ibidem, vol. I, pp. 372-373.

79 Ibidem, vol. I, p. 373, vol. II, p. 827.

${ }^{80}$ See I. Różycki, Tradycja jako norma bliska. Nowa interpretacja orzeczeń trydenckich w sprawie grzechu pierworodnego, „Analecta Cracoviensia” 5-6 (1973-1974), pp. 442-450.

81 Ibidem, p. 448. 
contemporary theologians. Although the literal reading of statements of the Magisterium of the Church of past ages may suggest that biological death did not appear in our world before Original Sin, it is clear that those statements require contemporary interpretation ${ }^{82}$. This does not mean that the Magisterium's doctrinal statements about "bodily death from which man would have been immune had he not sinned"83, even if there were some deficiencies in them ${ }^{84}$, were incorrect in terms of the truth communicated. Although they were based on incorrect assumptions on the grounds of exegesis and biblical interpretation ${ }^{85}$, they led to the correct conclusions: indeed, after sin, the whole human nature has changed for the worse ${ }^{86}$. This also applies to the phenomenon of bodily death. Although being a natural part of human existence, after the Fall of Man it is experienced as something that appeared in the world through sin (cf. Rom 6:23) instead of being experienced as a harmonious transition from mortal life to the eternity with God. It can be said that from the death experienced in such a way, man really "would have been immune had he not sinned". The biblical images of endless life granted by consumption of the fruits of the Tree of Life and the Magisterium's statements about the grace of original immortality are coherent and comprehensible if they are read in an eschatological perspective ${ }^{87}$. Such an interpretation is increasingly appreciated also by the very Magisterium of the Church as testified by the recent statement of its auxiliary body - the Pontifical Biblical Commission. In a document on biblical anthropology published by the Commission in 2019, the following reference to the issue can be found: "God (...) does not impose the death penalty on man. (...) Immortality - difficult to imagine for a transient creature - cannot be regarded as a lost gift, but as a promise for a future. It will be granted to a man if he humbly submits himself as being destined for the bodily death" $" 88$.

\section{Mariological evidence}

There is another important evidence that corroborates our interpretation of the issue of death as a consequence of sin proposed in this paper. This evidence is

${ }^{82}$ Cf. International Theological Commission, The Interpretation of Dogma (1989), https:// www.vatican.va/roman_curia/congregations/cfaith/cti_documents/rc_cti_1989_interpretazionedogmi_en.html [accessed 30.06.2021].

${ }_{83}$ Cf. Gaudium et spes, no. 18.

${ }^{84}$ Cf. Donum veritatis, no. 24.

${ }^{85}$ Cf. J. Ratzinger, Eschatologia - śmierć i życie wieczne, pp. 38-39.

${ }^{86}$ See Council of Trent, Decree on Original Sin (1546), no. 788.

${ }^{87}$ Cf. Papieska Komisja Biblijna, Czym jest człowiek? Zarys antropologii biblijnej, trans. H. Witczyk, Kielce 2020.

${ }^{88}$ Ibidem, no 321. Eng. trans. based on the Polish ed. 
based on the consistency of Christian anthropology with the doctrines of the Immaculate Conception and the Assumption of the Blessed Virgin Mary. If, confessing that Mary was preserved from all $\sin ^{89}$, one assumes that biological death is penalty for sin, then one also has to recognize that the Mother of God was taken into Heaven during Her earthly life, without experiencing - unlike Her Son - bodily death. That statement would be in accordance with the so-called immortalist interpretation of the Assumption of the Blessed Virgin Mary. It is, however, only one of two possible interpretations of the Assumption. There is also a different concept, the so-called mortalistic interpretation, according to which Holy Mary was assumed into Heaven (i.e., to the glory of the resurrection) after experiencing bodily death as a Dormition (as calls it Eastern theology).

The mortalistic variant is definitely better supported by arguments from the Christian tradition. It is supported by liturgical traditions, especially of the Eastern Churches ${ }^{90}$, apocryphal writings ${ }^{91}$ and material culture ${ }^{92}$. It should be noted that although the dogmatic definition of the Assumption of the Blessed Virgin Mary of 1950 does not explicitly recommend a mortalistic or immortalistic interpretation, it states that Mary "was assumed to the glory of heaven after complet-

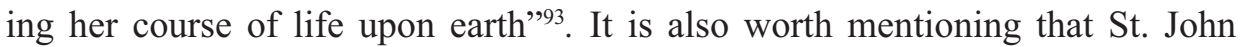
Paul II supported the mortalistic interpretation in his teaching ${ }^{94}$.

Therefore, we can assume that the Mother of God, before Her Assumption to the glory of the resurrection, experienced bodily death, which in Her case could

${ }^{89}$ See Pius IX, Bulla Ineffabilis Deus (1854) [in:] Breviarium fidei [new version], no. 527, fragmentary English transl.: Enchiridion symbolorum, no. 1641.

${ }^{90}$ See M. Blaza, Matka Boża w teologii prawostawnej, „Studia Bobolanum” 29 (2018) 1, pp. 37-38; Cf. A. Strus, Legenda, tradycja i historia o zaśnięciu i wniebowzięciu NMP, „Ruch Biblijny i Liturgiczny" 37 (1984) 2, p. 128.

${ }_{91}$ Both the Greek, like Dormition of Pseudo-John or Greek Transitus " $R$ ", Latin - especially Transitus of Pseudo-Melito of Sardis, Transitus of Pseudo-Joseph of Arimathea, as well as Syrian. See B. Kochaniewicz, Zaśnięcie i Wniebowzięcie Najświętszej Maryi Panny w pismach dominikanów XIII wieku, Roma 2004, pp. 78-79.

${ }_{92}$ In Jerusalem, at the foot of the Mount of Olives, there is the Church of the Sepulchre of Saint Mary. There is also the Abbey of Dormition on the Mount Zion. The location of these two places of worship corresponds to the narrative of apocryphal traditions describing the transfer of the body of the Mother of God from the place of Dormition to the Tomb from which the Assumption took place. Cf. Transitus Józefa z Arymatei [in:] Apokryfy Nowego Testamentu. Ewangelie apokryficzne. Part 2: Św. Józef i św. Jan Chrzciciel. Męka i zmartwychwstanie Jezusa. Wniebowzięcie Maryi, ed. M. Starowieyski, Kraków 2010, pp. 810-816; B. Kochaniewicz, Uwagi na temat tacińskiego apokryfu “Transitus Mariae” Pseudo-Józefa z Arymatei, „Salvatoris Mater” 7 (2005) 1, pp. 266-267.

93 Pius XII, Apostolic Constitution "Munificentissimus Deus". Defining the Dogma of the Assumption, orig. text: „Acta Apostolicae Sedis” 42 (1950), pp. 753-773, fragmentary English trans.: Enchiridion symbolorum, no. 2331-2333.

94 John Paul II, General Audience 25 June 1997, https://www.vatican.va/content/john-paul-ii/ en/audiences/1997/documents/hf_jp-ii_aud_25061997.html [accessed 30.06.2021]. 
be called a "Dormition". At the same time, the Church teaches that Virgin Mary was preserved from all sin, including Original $\mathrm{Sin}^{95}$. If so, bodily death cannot be perceived as penalty of sin, a consequence of the Fall. Instead, it should be stated that for a man who is closely united with God - like Mary, Full of Grace - the end of mortal life has a different character than for a sinner. It becomes a transition (transitus) to an eternity in the God's presence ${ }^{96}$.

It is not possible to elaborate on the topic of the mariological aspect of the issue in this article, thus the author can only refer the reader to the paper that awaits to be printed in The Theological Yearbook ("Rocznik Teologiczny") ${ }^{97}$.

\section{Conclusion}

To summarize the findings of this paper, it can be concluded that, although the narrative of the Fall in (Gen 2-3) describes bodily death as a result of sin, it should be interpreted as a metaphor of spiritual death, which is a primary consequence of the Fall. In other words, the narrative conveys the truth that sin results in eternal, spiritual death. Moreover, the Bible distinguishes between the biological and spiritual death. Biological death is shown as something natural for every man, and spiritual (eternal) one as the fate of sinners. This biblical view on the issue is reflected in the doctrinal statements of the Church throughout history. However, since some of the statements of the Magisterium, which say that man would not have died if he had not sinned, seem to contradict the fact that transience is something omnipresent on Earth, they require interpretation. In this article we proposed the following interpretation: if man had not sinned, death would not have been experienced as a tragic and fearsome occurrence. It would rather be a "dormition", a peaceful transition from earthly to eternal life, as it was in the case of the Blessed Virgin Mary, who was free from all sin, i.e.: Full of Grace.

Such an interpretation solves the difficulties presented in introduction, has a strong support in the biblical content and does not contradict the entire content of the Christian faith, especially the mariological dogmas. A significant advantage of the interpretation proposed in this paper is its compliance with the Catholic principles of a dogma interpretation. It does not deviate from the universal teaching (ordinary and extraordinary) of the Magisterium of the Church of the past ages, nor does it contradict the expressions and terminology used in

95 See Pius IX, Ineffabilis Deus (1854).

96 See Lumen Gentium, no. 53.

97 Titled: Argumentacja mariologiczna i hagiologiczna na rzecz wspótczesnej interpretacji teologicznej nauczania Magisterium Kościoła Katolickiego o śmierci jako skutku grzechu [Mariological and hagiological argumentation for the modern theological interpretation of Catholic doctrine of death as a result of original $\sin ]$. 
Magisterium's statements. The meaning of dogmatic definitions is also preserved in this interpretation ${ }^{98}$.

Obviously, we cannot state that the interpretation presented above is the only correct way to explain the issue of death as a consequence of sin. Although many contemporary theologians express similar position, stating that biological death as a phenomenon in itself should not be perceived as a consequence of sin, one should recognize the right of theologians to express the opposite opinion ${ }^{99}$. We dare to state, however, that the interpretation presented in this paper provides a better response to the theological difficulties around the issue of death as a consequence of $\sin$.

\section{Summary}

There is an apparent contradiction between the catholic doctrine of death as a result of the Original Sin and the fact that the biological death is a common and somewhat necessary phenomenon in the world of nature. Analysis of biblical data and interpretation of the Magisterium of the Church's dogmatic teaching allows us to propose a solution to the problem by stating that the primary consequence of sin is spiritual death, that is, breaking communion with God, and bodily death is only a secondary, consequence result of sin, which means that the experience of bodily death has changed for man after the fall. This proposal is corroborated by opinions of some recognized contemporary theologians.

\section{Keywords}

original sin, fall of man, death, bodily death, transience, immortality, proctology

\section{W stronę wspólczesnej interpretacji teologicznej zagadnienia śmierci jako skutku grzechu}

\section{Streszczenie}

Istnieje pozorna sprzeczność pomiędzy katolickim nauczaniem o śmierci jako skutku grzechu a faktem, że śmierć biologiczna jest zjawiskiem powszechnym i poniekąd koniecznym w świe-

${ }^{98}$ See Dei Filius, canon IV.3; International Theological Commission, The Interpretation of Dogma, no. III.5; Mysterium Ecclesiae, no 5.

99 The opinion that bodily death appeared in this world after the Fall is expressed, among Polish theologians, by Fr. prof. Jacek Salij, (see J. Salij, Przekleństwo śmierci i śmierć w Chrystusie. Próba teologii śmierci [in:] Śmierć $i$ wiara $w$ życie pośmiertne $w$ świetle nauk przyrodniczych $i$ humanistycznych, ed. M. Machinek, Olsztyn 2003, pp. 229-240), and also M. Wojciechowski (see M. Wojciechowski, Pochodzenie świata, człowieka, zła. Odpowiedź Biblii, Częstochowa 2005, p. 64). 
cie przyrody. Analiza danych biblijnych oraz interpretacja dogmatyczna wypowiedzi Magisterium pozwala na sformułowanie propozycji rozwiązania owej trudności. Zakłada ona, że obiektywnym skutkiem grzechu jest śmierć duchowa, czyli zerwanie komunii z Bogiem, natomiast śmierć cielesna jest skutkiem jedynie subiektywnym: w znaczeniu zmiany charakteru tego doświadczenia dla człowieka. Twierdzenia takie znajdują poparcie w myśli uznanych, współczesnych teologów.

\section{Slowa kluczowe}

grzech pierworodny, upadek, śmierć, śmierć cielesna, przemijanie, nieśmiertelność, protologia

\section{Bibliography}

A Selected Library of the Nicene and Post-Nicene Fathers of the Christian Church, ed.

P. Schaff, H. Wace, Edinburgh 1899.

Acta synodalia I: Dokumenty synodów [Acta synodalia] - od 50 do 381 roku. Synody

i kolekcje praw, ed. A. Baron, H. Pietras, vol. I, Kraków 2006.

Acta synodalia II: Dokumenty synodów [Acta synodalia] - od 381 do 431 roku. Synody

i kolekcje praw, ed. A. Baron, H. Pietras, vol. IV, Kraków 2010.

Acta synodalia IV: Dokumenty synodów [Acta synodalia] - od 506 do 553 roku. Synody

i kolekcje praw, ed. A. Baron, H. Pietras, vol. VIII, Kraków 2014.

Bartnik Cz.S., Dogmatyka katolicka, vol. I, Lublin 2009.

Bartnik Cz.S., Dogmatyka katolicka, vol. II, Lublin 2012.

Biblia pierwszego Kościoła, ed. \& trans. R. Popowski, Warszawa, 2017.

Blaza M., Matka Boża w teologii prawosławnej, „Studia Bobolanum” 29 (2018) 1, pp. 23-45.

Bortkiewicz P., Tanatologia. Czy istnieje nauka o śmierci? [in:] Śmierć i wiara w życie pośmiertne $w$ świetle nauk przyrodniczych i humanistycznych, ed. M. Machinek, Olsztyn 2003, pp. 11-24.

Brown R.E., I Bogiem bylo stowo. Komentarz do Ewangelii wg św. Jana, trans. A. Gomola, Kraków 2010.

Council of Trent, Decree on Original Sin (1546) [in:] Enchirdion symbolorum, no. 787-792 [Polish trans.: Dokumenty Soborów IV, pp. 235-241].

Dei verbum: Second Vatican Council, Dogmatic Constitution on Divine Revelation "Dei verbum” (1965), https:/www.vatican.va/archive/hist_councils/ii_vatican_council/ documents/vat-ii_const_19651118_dei-verbum_en.html [accessed 30.06.2021].

Dokumenty Soborów I: Dokumenty Soborów Powszechnych. Nicea I, Konstantynopol I, Efez, Chalcedon, Konstantynopol II, Konstantynopol III, Nicea II (325-787), trans. A. Baron et al., ed. A. Baron, H. Pietras, vol. I, Kraków 2002.

Dokumenty Soborów III: Dokumenty Soborów Powszechnych (1414-1445). Konstancja, Bazylea-Ferrara-Florencja-Rzym, trans. A. Baron et al., ed. A. Baron, H. Pietras, vol. III, Kraków 2004. 
Dokumenty Soborów IV: Dokumenty soborów powszechnych (1511-1870). Lateran V, Trydent, Watykan I, trans. A. Baron et al., ed. A. Baron, H. Pietras, vol. IV, Kraków 2004.

Donum Veritatis: Congregation for the Doctrine of the Faith, Instruction "Donum Veritatis" on the Ecclesial Vocation of the Theologian, (1990), https://www.vatican.va/ roman_curia/congregations/cfaith/documents/rc_con_cfaith_doc_19900524_theologian-vocation_en.html [accessed 30.06.2021].

Enchiridion symbolorum: Enchiridion symbolorum definitionum et declarationum de rebus fidei et morum, ed. H. Denzinger, K. Rahner, Romae 1957; English translation: The Sources of Catholic Dogma, trans. R.J. Deferrari, Fitzwilliam 2002.

Epos o Gilgameszu, trans. \& ed. K. Łyczkowska et al, Warszawa 2002.

Gaudium et spes: Second Vatican Council, Pastoral Constitution of the Church in the Modern World, "Gaudium et Spes" (1965), https://www.vatican.va/archive/hist_ councils/ii_vatican_council/documents/vat-ii_const_19651207_gaudium-et-spes_ en.html [accessed 30.06.2021].

Granat W., Bóg Stwórca. Aniołowie - człowiek, Lublin 1961.

Historia dogmatów II: Grossi, V., Ladaria L.F., Lécrivain P., Sesboüé B., Człowiek i jego zbawienie: stworzenie, grzech pierworodny, usprawiedliwienie i łaska, rzeczy ostateczne, etyka chrześcijańska: od „, autorytetów” do Magisterium, trans. P. Rak, vol. II, Kraków 2001.

John Paul II, General Audience 25 June 1997, https:/www.vatican.va/content/john-paul-ii/ en/audiences/1997/documents/hf_jp-ii_aud_25061997.html [accessed 30.06.2021].

Jelonek T., Biblia a mity o raju i złotym wieku, Kraków 2010.

Jelonek T., Biblijna historia zbawienia, Kraków 2004.

Katechizm Kościoła Katolickiego, Poznań 2020.

Katolicki Komentarz Biblijny, trans. K. Bardski et al., ed. R.E. Brown, J.A. Fitzmyer, R.E. Murphy, Warszawa 2004.

Kijas Z.J., Początki świata i człowieka, Kraków 2004.

Kochaniewicz B., Uwagi na temat łacińskiego apokryfu „,Transitus Mariae” Pseudo-Józefa z Arymatei, „Salvatoris Mater” 7 (2005) 1, pp. 263-287.

Kochaniewicz B., Zaśnięcie i Wniebowzięcie Najświętszej Maryi Panny w pismach dominikanów XIII wieku, Roma 2004.

Mysterium Ecclesiae: Congregation for the Doctrine of the Faith, Declaration in Defense of the Catolic Doctrine on the Church Against Certain Errors of the Present Day ["Mysterium Ecclesiae"] (1973), https://www.vatican.va/roman_curia/congregations/cfaith/documents/rc_con_cfaith_doc_19730705_mysterium-ecclesiae_en.html [accessed 30.06.2021].

Ladaria Ferrer L.F., Wprowadzenie do antropologii teologicznej, trans. A. Baron, Kraków 1997.

Lemański J., Księga Rodzaju. Rozdziały 1-11. Nowy Komentarz Biblijny. Stary Testament, vol. I, part 1, Częstochowa 2013. 
Lumen gentium: Second Vatican Council, Dogmatic Constitution on the Church "Lumen gentium” (1964), https://www.vatican.va/archive/hist_councils/ii_vatican_council/ documents/vat-ii_const_19641121_lumen-gentium_en.html [accessed 30.06.2021].

Łach J.B. Księgi Ludu Bożego Starego Przymierza: Pięcioksiag, Prorocy, Pisma. Ujęcie teologiczno-praktyczne, Poznań 2018.

Łach S., Księga Rodzaju. Wstęp, przekład z oryginalu, komentarz, Poznań 1962.

Methodius of Olympus, The Banquet of the Ten Virgins or Concerning Chastity, trans. W.R. Clark [in:] The Writings of Methodius, Alexander of Lycopolis, Peter of Alexandria and several fragments, ed. A. Roberts, J. Donaldson, Edinburgh 1869, pp. 1-119.

International Theological Commission, The Interpretation of Dogma (1989), https:// www.vatican.va/roman_curia/congregations/cfaith/cti_documents/rc_cti_1989_ interpretazione-dogmi_en.html [accessed 30.06.2021].

Międzynarodowy komentarz do Pisma Świętego. Komentarz katolicki i ekumeniczny na XXI wiek, ed. W.R. Farmer et al., Warszawa 2000.

Müller G.L., Dogmatyka katolicka, trans. W. Szymona, Kraków 2015.

New English Translation of the Septuagint, Oxford 2007.

Niemiecka Konferencja Biskupów, Katolicki katechizm dorosłych. Wyznanie wiary Kościoła, trans. M. Węcławski, Poznań 1991.

Nossol A., Teologia na ustugach wiary. Wokół zagadnień odnowionej teologii, Opole 1978.

Papieska Komisja Biblijna, Czym jest człowiek? Zarys antropologii biblijnej, trans. H. Witczyk, Kielce 2020.

Papieska Komisja Biblijna, Interpretacja Pisma Świętego w Kościele, trans. K. Romaniuk, Poznań 1994.

Piotrowski E., Kara wieczna a grzech pierworodny. Konieczność debaty, „Verbum Vitae” 36 (2019), pp. 285-314.

Pius IX, Ineffabilis Deus (1854) [in:] Breviarium fidei [new version], no. 527, fragmentary English transl.: Enchiridion symbolorum, no. 1641.

Pius XII, Apostolic Constitution "Munificentissimus Deus" Defining the Dogma of the Assumption, orig. text: „Acta Apostolicae Sedis” 42 (1950), pp. 753-773, fragmentary English trans.: Enchiridion symbolorum, no. 2331-2333.

Pius V, Ex omnibus afflictionibus (1567) [in:] Enchiridion symbolorum, no. 1078.

Pius VI, Constituion Auctorem fidei (1794) [in:] Enchiridion symbolorum, no. 1517.

Przyszychowska M., Wszyscy byliśmy w Adamie. Jedność ludzkości w Adamie w nauczaniu ojców Kościoła, Poznań 2013.

Rahner K. Podstawowy wykład wiary. Wprowadzenie do pojęcia chrześcijaństwa, trans. T. Mieszkowski, Warszawa 1987.

Ratzinger J., Eschatologia - śmierć i życie wieczne, trans. M. Węcławski, Poznań 1985. Ratzinger J., Kościót - znak wśród narodów, vol. I, [Opera Omnia VIII/1], Lublin 2013. Ratzinger J., Wprowadzenie do chrześcijaństwa, [Opera Omnia IV], Lublin 2017.

Różycki I., Tradycja jako norma bliska: nowa interpretacja orzeczeń trydenckich $w$ sprawie grzechu pierworodnego, „Analecta Cracoviensia” 5-6 (1973-1974), pp. 423-450. 
Salij J., Przekleństwo śmierci i śmierć w Chrystusie. Próba teologii śmierci [in:] Śmierć $i$ wiara $w$ życie pośmiertne $w$ świetle nauk przyrodniczych $i$ humanistycznych, ed. M. Machinek, Olsztyn 2003, pp. 229-240.

Sobór Watykański I, Konstytucja dogmatyczna o wierze katolickiej „Dei Filius” [in:] Dokumenty soborów powszechnych (1511-1870). Lateran V, Trydent, Watykan I, trans. A. Baron et al., ed. A. Baron, H. Pietras, vol. IV, Kraków 2004, pp. 889-911.

Stanek T., Pięcioksiag jako narracja symboliczna, Poznań 2014.

STh: Tomasz z Akwinu, Suma teologiczna, I, q. 85-102: Człowiek, trans. \& ed. P. Bełch, vol. VII, Londyn 1980.

Strus A., Legenda, tradycja i historia o zaśnięciu i wniebowzięciu NMP, „Ruch Biblijny i Liturgiczny" 37 (1984) 2, pp. 127-139.

Synowiec J.S., Początki świata i ludzkości wedtug Księgi Rodzaju, Kraków 2001.

The Ignatius Bible: Revised Standard Version, Second Catholic Edition, San Francisco 2005.

Transitus Józefa z Arymatei [in:] Apokryfy Nowego Testamentu. Ewangelie apokryficzne. Part 2: Św. Józefi św. Jan Chrzciciel. Męka i zmartwychwstanie Jezusa. Wniebowzięcie Maryi, ed. M. Starowieyski, Kraków 2010, pp. 810-816.

Trilling W., Stworzenie i upadek wedtug Rdz 1-3, trans. E. Schulz, Warszawa 1980.

Tronina A., Drzewo życia w rajskim ogrodzie. Biblijne korzenie mistyki Krzyża, Częstochowa 2017.

Tutaj A., Gaśnięcie świadomości. Starzenie się i obumieranie ludzkiego mózgu [in:] Śmierć $i$ wiara $w$ życie pośmiertne $w$ świetle nauk przyrodniczych $i$ humanistycznych, ed. M. Machinek, Olsztyn 2003, pp. 27-30.

Verbum Domini: Benedict XVI, Post-Synodal Apostolic Exhortation "Verbum Domini" (2010), https://www.vatican.va/content/benedict-xvi/en/apost_exhortations/documents/ hf_ben-xvi_exh_20100930_verbum-domini.html [accessed 30.06.2021].

Witała M., Grzech pierworodny: współczesne trudności i propozycja zastosowania chrystocentrycznej symboliki drzew rajskich $w$ narracji teologicznej, ,Teologia Dogmatyczna" vol. 15 (2020), pp. 209-224.

Wojciechowski M., Pochodzenie świata, człowieka, zła. Odpowiedź Biblii, Częstochowa 2005. 